Fidei: Jurnal Teologi Sistematika dan Praktika, Vol. 4, No. 1, Juni 2021

Fidei: Jurnal Teologi Sistematika dan Praktika

Terakreditasi No: 85/M/KPT/2020 (Sinta 4)

e-ISSN: $2621-8135$

http://www.stt-tawangmangu.ac.id/e-journal/index.php/fidei

Vol. 4 No.1 (Juni 2021) hlm: 44-60

p-ISSN: 2621-8151

DOI: https://doi.org/10.34081/fidei.v4i1.184

\title{
Strategi Pelaksanaan Amanat Agung Era New Normal Terhadap Kelompok Terdampak Ekonomi
}

\author{
Yohanes Parapat, Mark Phillips Eliasaputra ${ }^{1{ }^{*}}$ \\ 1) Sekolah Tinggi Teologi Ekumene, Indonesia \\ *) E-mail: yohanes.asp@gmail.com
}

Diterima: 10 Okt. 2020

Direvisi: 08 Mei 2021

Disetujui: 01 Juni 2021

\begin{abstract}
Abstrak
Pandemi Covid-19 memberikan persoalan baru bagi gereja dalam melaksanakan misinya, khususnya terhadap kelompok terdampak ekonomi. Artikel ini bertujuan mengusulkan strategi misi sesuai Amanat Agung, di era pasca pandemi atau "the new normal". Studi menggunakan metode kualitatif deskriptif dan pengumpulan data dilakukan dengan kajian literatur. Dengan pemahaman dan persiapapan untuk pelaksanaan misi sesuai Amanat Agung secara holistik, pemanfaatan teknologi serta sumber daya manusia militan yang berkomitmen, gereja dapat melakukan panggilan misinya dengan efektif, khususnya kepada kelompok yang terdampak pandemi Covid-19 secara ekonomi, baik pekerja maupun pengusaha. Pandemi Covid-19 memunculkan tantangan sekaligus peluang bagi gereja menjalankan panggilan misinya dan menghasilkan buah bagi Tuhan.
\end{abstract}

Kata-Kata Kunci: Amanat Agung; Kenormalan Baru; Pandemi Covid-19; Strategi Misi; Teknologi Informasi.

\section{Abstract}

The Covid-19 pandemic presents new problems for the church in carrying out its mission, especially for groups affected in the economy aspect. This article aims to suggest a mission strategy according to the Great Commission, in the post-pandemic era or "the new normal". The study used descriptive qualitative methods and data collection was conducted with a literature review. With 
understanding and preparation for carrying out missions according to the Great Commission in holistic, using information technology and committed and militant human resources, the church can carry out its mission calls effectively, especially to the groups that economically affected, both workers and employers. The Covid-19 pandemic presents both challenges and opportunities that the church can utilized to fulfill its mission call and be friutful to God.

Keywords: Covid-19 pandemic; Lecturer Role; Online Learning Problems.

\section{Pendahuluan}

Penyakit Covid-19 yang telah dinyatakan sebagai pandemi oleh Organisasi Kesehatan Dunia WHO, disebabkan oleh virus SARS-CoV-2 (novel coronavirus), dan menyebabkan perubahan besar dalam kehidupan manusia di hampir semua negara, termasuk di Indonesia. Setiap orang diminta seoptimal mungkin menjalankan social distance (bukan hanya secara fisik tetapi juga sosial dalam konteks pertemuan). Selanjutnya penggunaan masker standar dunia kesehatan internasional yang mencakup penutupan mulut dan hidung, serta memastikan untuk membersihkan tangan dengan cara yang benar. Pemerintah kemudian juga menyerukan agar masyarakat semaksimal mungkin tetap di rumah saja jika tidak benar-benar memiliki kepentingan yang mendesak untuk keluar. Lebih jauh, pemerintah bahkan mengeluarkan perintah pembatasan sosial untuk mengurangi penyebaran pandemi ini, yang dikenal dengan Pembatasan Sosial Berskala Besar (PSBB).

Disamping ancaman langsung penyakit Covid-19 terhadap tubuh fisik, dampak besar pandemi juga terganggunya kesehatan mental masyarakat akibat berita-berita seputar kematian serta efek buruk yang dialami mereka yang terpapar, ditambah stigma sebagian masyarakat yang negatif terhadap penderitanya. Penelitian yang dilakukan oleh Perhimpunan Dokter Spesialis Kedokteran Jiwa Indonesia (PDSKJI) menemukan, 63\% responden yang berasal dari berbagai kalangan mengalami gangguan cemas dan $66 \%$ menjadi depresi akibat pandemi Covid-19, dengan gejala kekhawatiran yang berlebihan akan terjadinya hal yang buruk, menurunnya semangat dan harapan, bahkan sampai keinginan untuk mengakhiri hidup. ${ }^{1}$

Selain dalam bidang kesehatan, dampak besar dari pembatasan terhadap aktivitas di luar rumah (PSBB) lainnya ada pada aspek ekonomi. Para

${ }^{1}$ Ilham Akhsanu Ridlo, "Pandemi Covid-19 Dan Tantangan Kebijakan Kesehatan Mental Di Indonesia," Insan - Jurnal Psikologi dan Kesehatan Mental 5, no. 2 (2020): 155-164. 
pengusaha besar maupun kecil, baik di bidang produk maupun jasa yang berusaha secara langsung maupun daring, banyak yang mengalami penurunan omset yang siginifikan, dan sebagian sampai harus menutup usaha karena bangkrut. ${ }^{2}$ Sementara bagi para pekerja, efek yang menimpa pengusaha berimbas berkurangnya pekerjaan yang tersedia, yang pada gilirannya bedampak pada berkurangnya kebutuhan tenaga kerja atau pekerja, sehingga pemotongan upah hingga Pemutusan Hubungan Kerja (PHK) tidak dapat dihindari. Data sampai pertengahan tahun 2020 menunjukkan 15,6\% pekerja mengalami PHK selama masa PSBB dan 39,6\% mengalami penurunan pendapatan, dan sebagian diantaranya turun lebih dari $50 \% .^{3}$

Dari kondisi diatas, bagi kelompok pengusaha maupun pekerja, disamping dampak ekonomi yang dialami secara langsung, ancaman permasalahan kesehatan mental berupa depresi dan keputusasaan, menjadikan resiko dan persoalan yang dihadapi menjadi semakin tinggi. Dalam keadaan ini, Injil yang merupakan kabar baik bagi mereka yang kehilangan harapan, menjadi sangat penting untuk dapat tersampaikan dengan baik kepada kedua kelompok diatas. Namun persoalannya, bagaimana gereja harus menyusun dan menerapkan strategi misi pemberitaan Injil yang efektif bagi kelompok yang mengalami resiko ganda ini. Bagi para pemimpin jemaat atau gereja, situasi ini menciptakan persoalan sekaligus tantangan baru dalam melayani pekerjaan Tuhan. Di satu sisi gereja harus merubah sebagian besar bentuk pelayanannya (termasuk dalam hal misi pemberitaan Injil dalam konteks ini) dari bertemu langsung menjadi bentuk daring (digital), sehingga harus memastikan efektifitas pelayanan dapat tercapai, dan mereka yang dilayani terpenuhi kebutuhannya. Dari sisi lain, dalam aspek teknis, meskipun dengan perkembangan di dunia informasi dan komunikasi hal tersebut memang dimungkinkan, namun ada persoalan dalam penguasaan teknologi, yang tidak semua gereja memilikinya.

Berdasarkan permasalahan diatas, artikel ini bertujuan untuk mengusulkan suatu strategi pelaksanaan misi pascapandemi Covid-19, atau lebih dikenal era "the new normal" (kenormalan baru), khususnya kepada kedua kelompok yang paling terdampak secara ekonomi. Strategi yang dimaksud disini suatu pendekatan yang menyeluruh dalam melaksanakan panggilan misi sebagaimana

${ }^{2}$ Taufik Taufik and Eka Avianti Ayuningtyas, "Dampak Pandemi Covid 19 Terhadap Bisnis Dan Eksistensi Platform Online,” Jurnal Pengembangan Wiraswasta 22, no. 01 (2020): 21.

${ }^{3}$ Ngadi Ngadi, Ruth Meliana, and Yanti Astrelina Purba, "Dampak Pandemi Covid-19 Terhadap Phk Dan Pendapatan Pekerja Di Indonesia," Jurnal Kependudukan Indonesia 29, no. 02 (2020): 43. 
dimaksudkan oleh Yesus Kristus dalam Amanat Agung-Nya. Hal itu berarti bukan hanya pemberitakan Injil, melainkan sampai seseorang menjadi murid Yesus Kristus dan diajarkan firman Allah (Mat 28:19-20), dalam kondisi pascapademi yang menuntut perubahan pendekatan akibat pembatasan aktivitas fisik langsung, yang memang perlu dilakukan.

\section{Metode Penelitian}

Studi dilakukan menggunakan metode kualitatif deskriptif. Data yang digunakan dalam studi ini dikumpulkan dengan metode studi literatur. Dalam metode deskriptif pertama-tama akan ditinjau konsep misi sesuai Amanat Agung Yesus Kristus dalam Matius 28:18-20. Selanjutnya, akan diuraikan secara deskriptif strategi misi yang diusulkan untuk kondisi kenormalan baru, khususnya di Indonesia. Penggunaan definisi dari pendekatan militeristik digunakan, sebab sejalan dengan kata "misi" yang merupakan terminologi teknik di bidang militer. ${ }^{4}$

\section{Pembahasan dan Hasil}

\section{Misi dan Amanat Agung}

Kata misi berasal dari kata dalam bahasa Latin Missio yang merupakan bentuk substantif dari mittere, suatu kata kerja. Dalam kedua bahasa, Latin dan Yunani, misi lebih cenderung memiliki arti mengutus atau bisa juga mengirim. Khusus dalam teks Yunani, kata lainnya yang terkait misi adalah 'apostello' (sering diterjemahkan mengutus) dan 'ретро' (lebih sebagai mengirim). Secara luas kata misi sendiri baru dipakai oleh Gereja mulai abad ke-17. ${ }^{5}$ Misi merupakan inisiatif Tuhan dalam sejarah yang berakar pada tujuan-Nya untuk memulihkan dan menyembuhkan ciptaan dan sebuah tema sentral biblikal. ${ }^{6}$ Dalam realita kehidupan tidak dapat dipungkiri misi Allah tersebut berlangsung di tengah konfrontasi kekuatan-kekuatan sejarah diantaranya ideologi, politik, sistem ekonomi, serta kegerakan keagamaan dan berbagai kondisi sosial. ${ }^{7}$

${ }^{4}$ Peter Cruchley-Jones, "Evangelism from the Margins: Experiences of the Ironic in Evangelism in Cardiff, UK," International Review of Mission 105, no. 1 (2016): 30-42, https://doi.org/10.1111/irom.12137.

${ }^{5}$ Markus Oci, "Implikasi Misiologi Dalam Pengembangan Kurikulum Agama Kristen Di Gereja Lokal,” Fidei: Jurnal Teologi Sistematika dan Praktika 2, no. 1 (2019): 81-99.

${ }^{6}$ Uma A Onwunta and H Jurgens Hendriks, "Missio Dei and Ethnic Diversity in Africa: A Reflection on the Metaphor of Community," Scriptura 101, no. 0 (2013): 314.

${ }^{7}$ Xolile Simon, "Mission As Frontier-Crossing and Identity Formation: An Integrating Contextual Missiology," Scriptura 100, no. 0 (2013): 89. 
Misi tidak terpisahkan dari Amanat Agung Tuhan Yesus karena merupakan esensi dan pusat dari amanat itu sendiri. Dengan kalimat lain namun dalam makna yang sama, melalui risetnya Kgatle menyimpulkan Amanat Agung yang diperintahkan Yesus Kristus pada hakekatnya sebuah seruan dan panggilan misi secara global. ${ }^{8}$ Nama "Amanat Agung" sendiri diambil dari judul yang diberikan oleh King James Version. ${ }^{9}$ Namun sekalipun disebut "agung", tidak dimaksudkan bahwa bagian tersebut lebih krusial atau superior dibanding bagian Injil lainnya, melainkan kesatuan integral.

Amanat agung yang dimaksud disini adalah istilah yang digunakan untuk perintah Yesus Kristus setelah Ia bangkit, untuk menyebarkan Injil ke seluruh dunia. Ada beberapa versi perintah ini dalam Alkitab, namun yang paling banyak digunakan adalah dari Matius 28:18-20. Lebih lanjut dalam pengamatannya Kgatle menyatakan meskipun sudah cukup banyak tulisan mengenai Amanat agung dibuat, namun mayoritas menguraikan dan menganalisis topik tersebut "dari sudut pandang teologi Kristen normatif: bagaimana makna dari perspektif Alkitab, urgensi dari misi Kristen dan implementasinya. Singkatnya apa yang harus dilakukan oleh orang Kristen mengenainya dan bagaimana harus menaati amanat agung Yesus Kristus."10

Itulah sebabnya sampai sekarang misi berdasarkan Amanat Agung banyak ditekankan dengan pergi memberitakan Injil dan membawa jiwa-jiwa baru kepada Kristus. Padahal seharusya tidaklah demikian. Hal ini diamati juga oleh Darmawan dengan melihat beberapa contoh, misalnya akibat adanya kata "pergilah" yang diletakkan di awal kalimat. ${ }^{11}$ Kata yang diterjemahkan

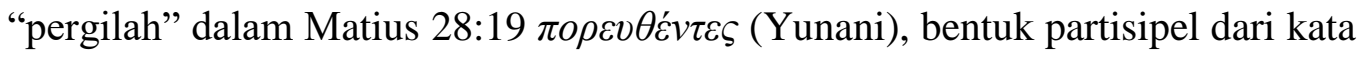

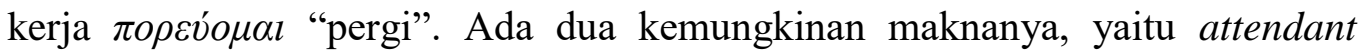
circumstance (pergilah) atau adverbial temporal (saat kamu pergi). Wallace mencatat ada perdebatan di antara para pakar, sekalipun ia lebih memilih attendant circumstance. Menurutnya, kata "Pergilah" lebih masuk akal daripada "Saat kamu pergi", yang menurutnya "menjadikan amanat agung sebagai Saran

${ }^{8}$ Mookgo S. Kgatle, "Globalisation of Missions: An Exegesis on the Great Commission (Mt 28:18-20)," In die Skriflig/In Luce Verbi 52, no. 1 (2018): 1-7.

${ }^{9}$ Mortimer Arias, "Church in the World: Rethinking the Great Commission," Theology Today 47, no. 4 (1991): 410-418. 20)."

${ }^{10}$ Kgatle, "Globalisation of Missions: An Exegesis on the Great Commission (Mt 28:18-

${ }^{11}$ I Putu Ayub Darmawan, "Jadikanlah Murid : Tugas Pemuridan Gereja Menurut Matius 28 : 18-20," Evangelikal: Jurnal Teologi Injili dan Pembinaan Warga Jemaat 3, no. 2 (2019): $144-153$. 
agung." 12 Tetapi apabila gereja menempatkan amanat agung sebagai gaya hidup seperti yang diteladankan oleh Tuhan Yesus sendiri dalam pengajaran, perbuatan dan pertolongan-Nya, maka penggunaan adverbial temporal di sini juga masuk akal, dalam pengertian orang percaya selalu memberitakan Injil dalam seluruh gerak hidupnya.

\section{Pemberitaan Injil dan Tanggung Jawab Sosial dalam Amanat Agung}

Prinsip penting lainnya misi dalam konteks Amanat Agung tidak boleh dimaknai hanya berbicara sisi upaya pemenangan jiwa melalui pemberitaan mengenai Yesus Kristus, baik dalam pemahaman "pergilah" ataupun "saat kamu pergi." Obrempong dalam tulisannya menjelaskan misi gereja dalam konteks Amanat Agung jelas memiliki dua tujuan, yaitu penjangkauan jiwa-jiwa dan tanggungjawab sosial. Keduanya sama-sama kritikal sebagai aktifitas misi gereja. $^{13}$

Ketika seseorang atau sekelompok orang menerima Kristus sebagai Tuhan dan juruselamat dari sebuah pemberitaan Injil, dibaptis dan akan diajar untuk menjadi murid Kristus melalui gereja, maka disitu ada proses dan waktu yang relatif panjang. Dalam kaitan ini gereja tidak mungkin mengabaikan tanggung jawab sosialnya khususnya kepada yang tidak mampu, mengalami masalah fisik dan psikis, penolakan keluarga, dan permasalahan ekonomi.

\section{Pemuridan Sebagai Esensi Amanat Agung}

Amanat agung Yesus bersifat mandataris-estafetis yang diekspresikan dalam empat kata kerja; pergilah, jadikanlah, baptislah dan ajarlah. Dari keempat kata kerja, menjadi utama dan merupakan perintah penting adalah menjadikan seseorang sebagai murid-Nya. Prinsipnya, jauh sebelum seseorang diutus selaku pemberita Injil, haruslah ia dimuridkan terlebih dahulu. Oleh karenanya dapat disimpulkan, sebelum pergi, dan kemudian membaptis serta mengajar, ada suatu proses pemuridan. Maknanya individu tersebut menjadi murid yang belajar dari seorang guru. Jadi ada semacam estafet yang harus ditempuh. ${ }^{14}$ Tidak kalah penting untuk ditekankan, pemuridan yang dilakukan dan diamanatkan Yesus, bertujuan agar setiap orang percaya mengalami

${ }^{12}$ Daniel B. Wallace, Greek Grammar Beyond the Basics: An Exegetical Syntax of the New Testament (Grand Rapids, MI: Zondervan, 1996).

13 James Nkansah-Obrempong, "Africa's Contextual Realities: Foundation for the Church's Holistic Mission," International Review of Mission 106, no. 2 (2017): 280-294.

${ }^{14}$ Tri Subekti, "Pemuridan Misioner Dalam Menyiapkan Perluasan Gereja Lokal," Epigraphe: Jurnal Teologi dan Pelayanan Kristiani 3, no. 2 (2019): 157. 
perubahan hidup, memiliki kasih seperti Kristus, diman itu cuma dimungkinkan melalui disiplin dalam melakukan firman Allah. ${ }^{15}$

Demikian juga ditinjau dari teks Yunaninya, dalam Matius 28:18-20, kata kerja dalam modus gramatikal imperatif ada pada kata "muridkanlah" $(\mu \alpha \theta \eta \tau \varepsilon v ́ \sigma \alpha \tau \varepsilon)$. Dua kata kerja lainnya yang diterjemahkan sebagai perintah dalam bahasa Indonesia, "baptislah" dan "ajarlah" dalam bahasa asli juga ditulis sebagai partisipel ( $\beta \alpha \pi \tau i \zeta o v \tau \varepsilon \varsigma$ dan $\delta i \delta \alpha ́ \sigma \kappa o v \tau \varepsilon \varsigma$ ), yang oleh Wallace dikategorikan sebagai participles of means (partisipel cara). Maksudnya, Yesus mengamanatkan para murid untuk memuridkan segala bangsa dengan cara membaptis dan mengajar mereka. ${ }^{16}$ Oleh karenanya misi dalam Amanat Agung tidak boleh berhenti pada memperkenalkan Kristus kepada orang-orang dan menjadikan mereka pemeluk agama Kristen, seolah-olah itu merupakan tujuan finalnya. Selanjutnya, dalam Amanat Agung juga penting diperhatikan mengenai siapa saja yang diperintahkan untuk dimuridkan. Tuhan Yesus memerintahkan untuk memuridkan segala bangsa ( $\pi \dot{\alpha} v \tau \alpha \tau \grave{\alpha}$ है $\theta v \eta$ ), tanpa membedakan latar belakang suku, bahasa, jenis kelamin, kelas sosial, dan warna kulit.

\section{Amanat Bagi Setiap Orang Percaya}

Yesus Kristus yang datang di bumi, ditentukan oleh Allah Bapa sebagai Tuhan atas semua manusia. Khususnya bagi orang percaya, semua tanpa terkecuali diminta oleh Kristus untuk terlibat di dalam misi-Nya, dan bukan sekedar sebagai penonton. Hal ini juga konsisten dengan 1 Petrus 2:9, dengan penekanan setiap orang percaya harus memahami dan memandang dirinya termasuk bangsa pilihan, kerajaan imamat, umat yang dikuduskan dan sepenuhnya milik Allah. Dalam ayat diatas ditegaskan maksud semua itu adalah agar seluruh umat Allah yang telah dilepaskan-Nya dari kegelapan, "pergi" menyatakan segala perbuatan-Nya yang agung, mulia dan besar. Pengertiannya disini ditujukan kepada gereja secara menyeluruh, dimana semua jemaat termasuk di dalamnya. ${ }^{17}$ Menurut Warren dalam kaitan ini salah satu pertanyaan

${ }^{15}$ K Yemima, "Strategi Pemuridan Mahasiswa Sekolah Tinggi Teologi Era New Normal Pandemi Covid-19," Jurnal Gamaliel: Teologi Praktika 2, no. 2 (2020): 68-81, https://nasional.kompas.com/read/2020/09/01/1528\%0Ahttp://jurnal.sttgamaliel.ac.id/index.php/gamaliel/article/view/56. Testament.

${ }^{16}$ Wallace, Greek Grammar Beyond the Basics: An Exegetical Syntax of the New

${ }^{17}$ Hery Susanto, “Gereja Yang Berfokus Pada Gerakan Misioner," Fidei: Jurnal Teologi Sistematika dan Praktika 2, no. 1 (2019): 62-80. 
yang harus kita ajukan untuk mengevaluasi kesehatan sebuah gereja ialah: berapa banyak yang digerakkan untuk melaksanakan misi berdasarkan Amanat Agung. ${ }^{18}$

\section{Dampak Pandemi Covid-19 Terhadap Perekonomian}

Disamping masalah kesehatan yang perlu diantisipasi dengan mengikuti protokol kesehatan sesuai panduan yang diberikan pemerintah, hal lain yang perlu diwaspadai dari pandemi Covid-19 yaitu potensi krisis ekonomi. Lembaga survei SMRC (Saiful Mujani Research \& Consulting) mengungkapkan bahwa pandemi ini sangat mempengaruhi perekonomian warga, apalagi yang bekerja di sektor informal dan kelompok pekerja yang mengandalkan pendapatan harian. ${ }^{19}$ Memandang sama Pandemi Covid-19 dengan wabah penyakit yang pernah terjadi sebelumnya tidaklah mungkin. Hal ini dikarenakan Covid-19 merupakan pandemi global, yang tidak hanya terpusat pada negara-negara dengan penghasilan rendah. Dengan kondisi dunia yang terintegrasi, maka side effect terjadi di sepanjang rantai pasok, dan juga terjadinya kehancuran penawaran dan permintaan sekaligus. ${ }^{20}$ Akibatnya, seluruh sektor perekonomian ikut terdampak. Produk domestik bruto negara-negara akan terpukul dalam kisaran $3-6 \%$ tergantung negaranya, bahkan ada yang sampai $10 \%$ hingga $15 \% .{ }^{21}$ Ini juga menyebabkan perusahaan-perusahaan mengurangi karyawannya, merumahkan sementara, dan ada juga yang sampai terpaksa berhenti beroperasi.

Ekses lainnya yang berdampak besar diantaranya keputusan sebagian perusahaan yang mengatakan akan mengubah cara karyawannya bekerja. Reporter BBC, Harper melaporkan, perusahaan-perusahaan raksasa teknologi seperti Facebook, Microsoft, Google, Amazon, juga Twitter akan menerapkan bekerja dari rumah sampai beberapa bulan atau bahkan seterusnya, atau setidaknya mengurangi jumlah hari kerja di kantor. Salah satu akibatnya pengurangan kebutuhan ruang kantor. ${ }^{22}$ Dampak lainnya seperti berkurangnya

${ }^{18}$ Rick Warren, The Purpose Driven Church - Gereja Yang Digerakkan Oleh Tujuan, 9th ed. (Malang: Gandum Mas, 2012).

${ }^{19}$ Ahmad Faiz Ibnu Sani, "Survei SMRC: 77 Persen Publik Merasa Covid-19 Ancam Penghasilan," accessed June 19, 2020, https://nasional.tempo.co/read/1332450/survei-smrc-77persen-publik-merasa-covid-19-ancam-penghasilan.

${ }^{20}$ Nuno Fernandes, "Economic Effects of Coronavirus Outbreak (Covid-19) on the World Economy Nuno Fernandes Full Professor of Finance IESE Business School Spain," SSRN Electronic Journal, ISSN 1556-5068, Elsevier BV, (2020): 0-29.

${ }^{21}$ Ibid.

22 Justin Harper, "Coronavirus: Flexible Working Will Be a New Normal after Virus," accessed June 8, 2020, https://www.bbc.com/news/business-52765165. 
kebutuhan alat transportasi tentu mempengaruhi bisnis dan ekonomi yang terkait.

\section{Strategi Misi Era Kenormalan Baru}

Untuk mencapai tujuan misi berupa pelaksanaan amanat agung dari Kristus Yesus dimana esensinya menjadikan segala bangsa murid-Nya, perlu disusun suatu strategi. Prinsip penting dalam menyusun strategi yaitu bahwa misi gereja merupakan partisipasi dalam missio Dei, dan pelaku utamanya adalah Allah Tritunggal. Namun demikian, sebagaimana ditegaskan oleh Prince dan Richards, ${ }^{23}$ manusia juga adalah agen yang integral dalam missio Dei, sebab "Allah Tritunggal Mahakudus telah memilih untuk bekerja melalui agen manusia bahkan dalam keadaan yang cacat dan berdosa. Gereja harus memandangnya bukan saja sebagai peluang penting, melainkan juga kepercayan dan kesempatan yang mungkin tidak terulang jika tidak disambut dan direspon dengan rasa hormat dan kegairahan yang kudus. Terkait hal ini, peran pemimpin gereja yang melalui teladan hidupnya dituntut mendewasakan jemaat ${ }^{24}$, berlaku juga dalam mempengaruhi kesukaan mereka terlibat bermisi.

\section{Strategi Untuk Kelompok Pekerja}

Meskipun misi harus menjangkau semua orang, pada kondisi pascapandemi perlu dipersiapkan secara spesifik strategi untuk menjawab kebutuhan beberapa kelompok orang, karena bersifat mendesak. Pertama untuk para karyawan termasuk buruh dan kelompok pekerja dalam sektor informal, yang terdampak kesulitan ekonomi sebagai imbas pandemi Covid-19. Efeknya antara lain PHK, dirumahkan, atau dipotong gaji, sebagaimana data yang disampaikan sebelumnya. Adanya dampak ekonomi, psikologis, dan sosial dari PHK akan memperburuk kualitas hidup dan kemampuan menjalankan fungsi sosialnya. Dampak ekonomi yang utama disini yaitu kehilangan pendapatan (income) tetap dari kelompok pekerja yang terdampak PHK dan sukarnya memperoleh suatu pekerjaan yang baru dalam konteks memenuhi kebutuhan diri sendiri dan juga keluarga bagi yang telah berumah tangga. Selanjutnya, terbentuknya gap atau kesenjangan besar secara ekonomi, dan akhirnya

${ }^{23}$ Janice Prince and Anne Richards, "The Restless Result between 'Is' and 'Ought,"' in Foundations for Mission, ed. Emma Wild-Wood and Peniel Rajkumar (Oxford, UK: Regnum, 2013), 17-29.

24 Yohanes Parapat, "Fungsi Gembala Jemaat Dalam Suksesi-Refleksi Atas Kepemimpinan Yesus Pada Model Gereja Otonom," Harvester 5, no. 2 (2020): 73-85. 
kemiskinan. Selanjutnya, dampak psikologis berupa munculnya ketidaksiapan secara mental para diri pekerja dalam menghadapi kondisi dari pra hingga pasca dialaminya PHK. Sedangkan dampak sosialnya adalah apa yang diistilahkan sebagai hilangnya identitas dalam aspek sosial yang bentuk riilnya rendah diri dan penolakan bersosialisasi dari komunitas. Belum lagi martabat keluarga yang bisa jadi terdampak terkait peran dan tanggung jawab, dimana sebelum kehilangan pekerjaan ada banyak yang biasanya bisa ikut ambil bagian didalamnya. ${ }^{25}$

Peliknya persoalan yang tidak dapat dihindari keluarga terdampak PHK adalah tidak adanya kepastian waktu untuk dapat kembali bekerja dan memperoleh penghasilan. Ditambah dengan biaya-biaya tetap seperti uang sekolah anak, angsuran atau sewa rumah dan kebutuhan primer lainnya sehubungan operasional rumah tangga. Persoalan seperti ini hampir pasti menciptakan tekanan psikologis atau kemudian memicu terjadinya stres. Hal inilah yang pada akhirnya dapat berujung pada depresi dan kehilangan harapan yang serius, bahkan tidak jarang berujung pada bunuh diri. ${ }^{26}$ Untuk itu, strategi misi untuk kelompok ini secara umum harus meliputi perbaikan atau bahkan sebisa mungkin memulihkan dan lebih lanjut mengembangkan individu secara kerohanian dan juga ketrampilan teknis. Untuk kelompok pekerja, strategi yang dibuat juga harus memuat konsep penanggulangan terhadap ketiga dampak tadi dengan dasar nilai-nilai kebenaran firman Allah.

Pertama-tama gereja perlu mempersiapkan konten yang spesifik dan relevan bagi kelompok pekerja ini sebagai "pintu masuk" jika mereka mencari informasi tentang pekerjaan atau spiritual secara daring. Diikuti oleh materi konseling yang kompherensif baik dalam hal pengenalan akan Allah dan juga materi kostruktif untuk menjawab dampak psikologis dan sosial yang umumnya terjadi.

Selanjutnya gereja dapat mempersiapkan dan memfasilitasi kursus dan pelatihan mengenai perintisan usaha kecil atau pembuatan suatu produk dan jasa, berdasarkan sumber dayanya. Secara paralel, bukan saja manfaat secara jasmani, tetapi terutama perjumpaan dengan Kristus menjadi yang terpenting dialami oleh mereka yang dapat ditolong, melalui orang-orang yang ada dalam gereja. Tidak kalah penting, semua pendekatan diatas, harus senantiasa

${ }^{25}$ D. Anisa Sunija et al., "Pekerja Sosial Industri Dalam Menangani Permasalahan Phk Di Dunia Industri Indonesia," Prosiding Penelitian dan Pengabdian kepada Masyarakat 6, no. 3 (2020): 181.

${ }^{26}$ Ridlo, "Pandemi Covid-19 Dan Tantangan Kebijakan Kesehatan Mental Di Indonesia." 
dilakukan secara simultan dengan prinsip kebenaran dan konsep misi dalam perspektif Amanat Agung sebagaimana telah diuraikan sebelumnya.

\section{Strategi Untuk Kelompok Pengusaha}

Dalam menangani pandemi Covid-19, pemerintah di banyak negara menetapkan pembatasan yang ketat terhadap perusahaan dalam berbagai industri, perintah jaga jarak dan sosial, kebijakan proteksi kesehatan dan bahkan penutupan usaha yang tidak esensial. ${ }^{27} \mathrm{Hal}$ ini tentu berdampak besar terhadap pengusaha, baik dalam skala usaha besar maupun menengah dan kecil, termasuk di Indonesia. Ditambah omset yang menurun tajam, kewajiban pembayaran gaji karyawan, tagihan vendor dan biaya-biaya lainnya yang tetap harus dipenuhi.

Para pengusaha ini melihat kenyataan virus yang tak kasat mata dapat merusak bisnis mereka. Disamping itu, mereka mengharapkan jawaban yang membantu tetapi juga realistis. Konten yang dirancang sebagai strategi penjangkauan oleh gereja dalam memperkenalkan Juru selamat Agung mesti memuat penjelasan yang membangun, logis dan realistis, sekaligus kebergantungan kepada Allah. Gereja dituntut profesional sekaligus dalam empati yang tulus. Bukan hanya sebagai pembuktian kepada manusia tetapi terlebih kepada Allah yang mempunyai misi, dimana gereja sebagai komunitas pengikut Kristus dipanggil, diajak dan disertakan dalam panggilan yang istimewa ini.

Kebenaran kokoh yang pertama harus dipegang oleh gereja dalam panggilan misinya kepada kelompok pengusaha adalah pemahaman bahwa pesan Injil relevan dan dapat menjangkau setiap kalangan, apapun latar belakang dan konteks kehidupannya. ${ }^{28}$ Ini bermakna tidak ada kelompok atau komunitas termasuk profesi yang tidak dapat dibawa kepada Kristus, melalui Injil. Oleh sebab itu, Injil harus disampaikan kepada kalangan pengusaha dengan keyakinan teguh, sebab merupakan kekuatan Allah sendiri yang karenanya sanggup menyelamatkan setiap orang (Rom. 1:16-17). Cara pandang ini harus menjadi dasar dalam membangun strategi penjangkauan komunitas yang dikenal kritis dan logis ini.

Setelah penyampaian Injil dilakukan dengan terbuka, jujur, sederhana dan kontekstual, selanjutnya pemuridan dilakukan melalui pendalaman Alkitab serta menempatkan para pengusaha ini dalam sebuah komunitas profesi yang sama

${ }^{27}$ Sascha Kraus et al., "The Economics of Covid-19: Initial Empirical Evidence on How Family Firms in Five European Countries Cope with the Corona Crisis," International Journal of Entrepreneurial Behaviour and Research, no. April (2020).

${ }^{28}$ David Eko Setiawan, "Menjembatani Injil Dan Budaya Dalam Misi Melalui Metode Kontektualisasi," Fidei: Jurnal Teologi Sistematika dan Praktika 3, no. 2 (2020): 160-180. 
untuk saling mencari kemungkinan bekerja sama diantara mereka, yang mungkin bisa dimulai meskipun dalam skala kecil pada awalnya. Bagi gereja yang mempunyai kemampuan keuangan lebih baik, memiliki momen untuk membuktikan kasih dan kebaikan Tuhan melalui gereja dengan mendukung secara permodalan. Secara finansial terutama setelah ekonomi pulih, sepanjang adanya transparansi yang lebih baik dalam operasi dan keuangan gereja, kelompok ini sangat berpotensi untuk mendukung misi gereja. Sebaliknya, jika gereja tidak menunjukkan kepedulian, maka kemungkinan orang-orang yang baru menjadi dalam konteks ini akan meninggalkan gereja sebelum dimuridkan akibat melihat betapa jauhnya antara yang diajarkan dengan prakteknya.

\section{Persiapan Gereja Untuk Pelayanan Misi Pascapandemi}

Untuk melaksanakan misi tersebut, gereja membutuhkan sumber daya yang sedapat mungkin memadai, khususnya aspek manusia (SDM). Petama, disamping para pendeta atau pemimpin gereja, pada era the new normal, gereja membutuhkan lebih banyak keterlibatan orang-orang yang memahami teknologi informasi, baik staf ataupun jemaat yang diberdayakan. Perlu dipersiapkan juga tim kreatif untuk membantu produksi konten digital yang baik dan menarik. Selain menarik, konten yang dibuat juga bermutu, jujur, dapat dipertanggung jawabkan, bersahabat dan tidak menyerang pihak lain termasuk agama lain. Khususnya konten-konten pelatihan usaha yang dibuka bagi orang-orang agama lain juga tidak perlu disisipi penginjilan terselubung yang dapat disalahpahami sebagai materi Kristenisasi dan berpotensi menimbulkan konflik dengan agama lain.

Selanjutnya, gereja perlu menginventarisir profesional di berbagai bidang usaha yang dimiliki sebagai narasumber yang menyiapkan materi pelatihan, kursus dan seminar sekaligus nantinya memimpin praktek memulai usaha jika memungkinkan. Dukungan pengadaan sumber daya teknologi seperti komputer dengan akses Internet broadband dan peralatan untuk siaran langsung (live streaming) yang memadai juga perlu dipertimbangkan dan diupayakan dengan serius sebab terbukti teknologi informasi sangat menolong sebuah gereja untuk tetap bisa melangsungkan kegiatan ibadah, persekutuan, bahkan pertemuan pengurus.

Disamping kesukaan jemaat untuk bermisi terus dikembangkan, mereka juga diajar dan dipersiapkan untuk memiliki pengetahuan tentang misi yang cukup sekaligus sikap militan dan komitmen yang kuat bagi Kristus, sebab 
seperti dikatakan oleh Stephanus, ${ }^{29}$ umat Allah haruslah memiliki gaya hidup penginjilan dalam model "suatu hidup yang memuat penuh kasih terhadap orang lain di lingkungan kita, yaitu orang-orang yang harus mendengar pesan Injil kemuliaan Tuhan." Untuk itu anggota jemaat perlu memiliki konsistensi untuk menghayati gaya hidup misioner ini karena kasih mereka kepada orang berdosa secara tulus dan otentik, baik dalam kehidupan di dunia nyata maupun melalui dunia maya. Optimisme untuk menang juga perlu diserukan, sebab misi didasari dan berdiri diatas janji penyertaan kekal dari Tuhan yang maha kuasa (Mat. 28:20b).

\section{Optimalisasi Teknologi Informasi}

Metode misi dalam the new normal jelas perlu mengalami modifikasi, dengan mengoptimalkan teknologi informasi baik untuk penginjilan pribadi, kelompok, maupun masal. Konten-konten berisi pengenalan akan Allah dalam bentuk video atau audio sebagai bagian strategi yang akan dijalankan, dirilis melalui YouTube, Facebook, Instagram, IGTV atau bahkan TikTok. Konten audio atau video dapat diunggah sebagai siniar / podcast, dimana materi secara otomatis dipindahkan ke komputer atau media pemutar lainnya. ${ }^{30}$

Konferensi video dapat dilakukan untuk pelatihan dan pendalaman Alkitab sebagai bagian pemuridan. Posting di media sosial harus terus dilakukan. Para pelayan di gereja Tuhan perlu secara kontinyu terhubung dengan individuindividu yang telah setuju dengan kerelaan memberi diri dimuridkan sebagai hasil penginjilan, baik melalui aplikasi pengiriman pesan maupun telepon. Pembentukan grup di aplikasi seperti WhatsApp juga sangat membantu.

Teknologi informasi mempermudah tindak lanjut kepada setiap pribadi yang bertemu Kristus melalui materi yang dibagikan gereja. Pekerja gereja menindaklanjuti melalui surel, aplikasi pengiriman pesan, maupun telepon. Dengan demikian pemuridan sebagai tugas utama dalam Amanat Agung dilakukan dengan pemanfaatan teknologi informasi secara optimal. Teknologi informasi juga akan membantu gereja dalam menerima persembahan misi dari jemaat dan juga pihak lain sepanjang tidak mengikat. Karena pandemi membuat orang tidak nyaman menggunakan uang tunai dan menyentuh barang-barang yang digunakan bersama dengan oran, maka gereja dapat memanfaatkan

${ }^{29}$ Djuwansah Suhendro P Stephanus, "Mengajarkan Penginjilan Sebagai Gaya Hidup Orang Percaya," Redominate 1, no. 1 (2019): 12-22.

${ }^{30}$ Efi Fadilah, Pandan Yudhapramesti, and Nindi Aristi, "Podcast Sebagai Alternatif Distribusi Konten Audio," Jurnal Kajian Jurnalisme 1, no. 1 (2017): 90-104. 
Electronic Data Capture atau dikenal sebagai mesin EDC yang menerima kartu debit, kartu kredit, dan bahkan uang elektronik, disamping transfer ke rekening. Menjadi krusial bagi gereja untuk transparan dalam keuangan. Bukan saja penting untuk meningkatkan kepercayaan semua orang dalam mendukung pelayanan misi melalui gereja, melainkan jauh lebih kritikal sebagai pertanggung jawaban terhadap Allah.

Masing-masing gereja dapat menyusun taktik berbasis kondisi jemaat sekaligus memobilisasi mereka sebagai bentuk pelaksanaan Amanat Agung di era the new normal ini dengan strategi diatas sebagai dasar. Ini penting agar seluruh jemaat semakin memahami penaggilan untuk melaksanakan misi dan diharapkan pada akhirnya menjadi kebiasaan bahkan kesukaan. Taktik utilisasi teknologi informasi dalam kerangka pelayanan misi sendiri bisa bermacammacam bentuknya, sepanjang gereja dapat menerima bahwa teknologi memungkinkan komunikasi, interaksi komunitas, dan proses pemuridan. ${ }^{31}$ Dalam konteks ini teknologi merupakan bagian tak terelakkan dari the new normal, dimana sebagian interaksi sebaiknya tidak dilakukan dalam bentuk secara langsung, termasuk dalam pelayanan misi antara gereja dengan umat. Oleh karenanya perlu dimengerti, tidak menjadi persoalan apakah misi bermula dari pemberitaan Injil sampai pemuridan dilakukan di dunia nyata dimana orang-orang bertemu langsung atau dalam lingkup dunia maya, sebab saat ini dunia tidak relevan untuk dipisahkan antara yang digital dan riil. ${ }^{32}$

\section{Simpulan}

Tantangan yang dijumpai gereja dalam situasi the new normal pascapandemi sangat unik. Namun demikian, panggilan Kristus kepada komunitas orang percaya perihal melaksanakan Amanat Agung-Nya tetap tidak berubah. Pandemi Covid-19 berpotensi membawa orang-orang, khususnya kelompok pekerja dan pengusaha dalam konteks artikel ini, untuk berpaling kepada Tuhan. Gereja harus siap untuk meraih kesempatan ini dan mencetak murid-murid baru untuk menjadi bagian kepemilikan Kristus. Untuk itu diperlukan pemahaman misi dalam konteks Amanat Agung secara holistik untuk kemudian mempersiapkan strategi yang tepat. Disamping itu dengan memanfaatkan teknologi serta sumber daya manusia dalam komitmen yang

${ }^{31}$ Yahya Afandi, "Gereja Dan Pengaruh Teknologi Informasi 'Digital Ecclesiology," Fidei: Jurnal Teologi Sistematika dan Praktika 1, no. 2 (2018): 270-283.

${ }^{32}$ Daniel Ronda, "Pemimpin Dan Media: Misi Pemimpin Membawa Injil Melalui Dunia Digital,” Jurnal Jaffray 14, no. 2 (2016): 197. 
utuh, peluang membawa sebanyak mungkin kelompok terdampak ekonomi bertemu Kristus, dipulihkan, bahkan menjadi lebih maju dalam aspek spiritual dan ekonomi, menjadi sangat dimungkinkan. Didukung dengan strategi yang tepat, ketaatan hidup kepada pimpinan Kristus sang Panglima Agung, dan penyertaan Roh Kudus, gereja akan benar-benar berbuah lebat bagi Tuhan (Mat 13:23; Mar 4:20; Luk 8:8).

\section{Daftar Pustaka}

Afandi, Yahya. "Gereja Dan Pengaruh Teknologi Informasi 'Digital Ecclesiology." Fidei: Jurnal Teologi Sistematika dan Praktika 1, no. 2 (2018).

Arias, Mortimer. "Church in the World: Rethinking the Great Commission." Theology Today 47, no. 4 (1991).

Cruchley-Jones, Peter. "Evangelism from the Margins: Experiences of the Ironic in Evangelism in Cardiff, UK." International Review of Mission 105, no. 1 (2016): 30-42. https://doi.org/10.1111/irom.12137.

Darmawan, I Putu Ayub. "Jadikanlah Murid : Tugas Pemuridan Gereja Menurut Matius 28: 18-20." Evangelikal: Jurnal Teologi Injili dan Pembinaan Warga Jemaat 3, no. 2 (2019).

Fadilah, Efi, Pandan Yudhapramesti, and Nindi Aristi. "Podcast Sebagai Alternatif Distribusi Konten Audio." Jurnal Kajian Jurnalisme 1, no. 1 (2017).

Fernandes, Nuno. "Economic Effects of Coronavirus Outbreak (Covid-19) on the World Economy Nuno Fernandes Full Professor of Finance IESE Business School Spain." SSRN Electronic Journal, ISSN 1556-5068, Elsevier BV, (2020).

Harper, Justin. "Coronavirus: Flexible Working Will Be a New Normal after

Virus." Accessed June 8, 2020. https://www.bbc.com/news/business52765165.

Kgatle, Mookgo S. "Globalisation of Missions: An Exegesis on the Great Commission (Mt 28:18-20)." In die Skriflig/In Luce Verbi 52, no. 1 (2018).

Kraus, Sascha, Thomas Clauss, Matthias Breier, Johanna Gast, Alessandro Zardini, and Victor Tiberius. "The Economics of Covid-19: Initial Empirical Evidence on How Family Firms in Five European Countries Cope with the Corona Crisis." International Journal of Entrepreneurial Behaviour and Research, no. April (2020).

Ngadi, Ngadi, Ruth Meliana, and Yanti Astrelina Purba. "Dampak Pandemi 
Covid-19 Terhadap Phk Dan Pendapatan Pekerja Di Indonesia." Jurnal Kependudukan Indonesia 29, no. 02 (2020).

Nkansah-Obrempong, James. "Africa's Contextual Realities: Foundation for the Church's Holistic Mission.” International Review of Mission 106, no. 2 (2017).

Oci, Markus. "Implikasi Misiologi Dalam Pengembangan Kurikulum Agama Kristen Di Gereja Lokal.” Fidei: Jurnal Teologi Sistematika dan Praktika 2, no. 1 (2019).

Onwunta, Uma A, and H Jurgens Hendriks. "Missio Dei and Ethnic Diversity in Africa: A Reflection on the Metaphor of Community." Scriptura 101, no. 0 (2013).

Parapat, Yohanes. "Fungsi Gembala Jemaat Dalam Suksesi - Refleksi Atas Kepemimpinan Yesus Pada Model Gereja Otonom." Harvester 5, no. 2 (2020).

Prince, Janice, and Anne Richards. "The Restless Result between 'Is' and 'Ought."' In Foundations for Mission, edited by Emma Wild-Wood and Peniel Rajkumar, 17-29. Oxford, UK: Regnum, 2013.

Ridlo, Ilham Akhsanu. "Pandemi Covid-19 Dan Tantangan Kebijakan Kesehatan Mental Di Indonesia." Insan - Jurnal Psikologi dan Kesehatan Mental 5, no. 2 (2020).

Ronda, Daniel. "Pemimpin Dan Media: Misi Pemimpin Membawa Injil Melalui Dunia Digital.” Jurnal Jaffray 14, no. 2 (2016).

Sani, Ahmad Faiz Ibnu. "Survei SMRC: 77 Persen Publik Merasa Covid-19 Ancam Penghasilan." Accessed June 19, 2020. https://nasional.tempo.co/read/1332450/survei-smrc-77-persen-publikmerasa-covid-19-ancam-penghasilan.

Setiawan, David Eko. "Menjembatani Injil Dan Budaya Dalam Misi Melalui Metode Kontektualisasi." Fidei: Jurnal Teologi Sistematika dan Praktika 3, no. 2 (2020).

Simon, Xolile. "Mission As Frontier-Crossing and Identity Formation: An Integrating Contextual Missiology." Scriptura 100, no. 0 (2013).

Stephanus, Djuwansah Suhendro P. "Mengajarkan Penginjilan Sebagai Gaya Hidup Orang Percaya." Redominate 1, no. 1 (2019).

Subekti, Tri. "Pemuridan Misioner Dalam Menyiapkan Perluasan Gereja Lokal." Epigraphe: Jurnal Teologi dan Pelayanan Kristiani 3, no. 2 (2019).

Sunija, D. Anisa, Septia Febriani, Santoso Tri Raharjo, and Sahadi Humaedi. 
60 Fidei: Jurnal Teologi Sistematika dan Praktika, Vol. 4, No. 1, Juni 2021

"Pekerja Sosial Industri Dalam Menangani Permasalahan Phk Di Dunia Industri Indonesia." Prosiding Penelitian dan Pengabdian kepada Masyarakat 6, no. 3 (2020).

Susanto, Hery. "Gereja Yang Berfokus Pada Gerakan Misioner." FIDEI: Jurnal Teologi Sistematika dan Praktika 2, no. 1 (2019).

Taufik, Taufik, and Eka Avianti Ayuningtyas. "Dampak Pandemi Covid 19 Terhadap Bisnis Dan Eksistensi Platform Online.” Jurnal Pengembangan Wiraswasta 22, no. 01 (2020).

Wallace, Daniel B. Greek Grammar Beyond the Basics: An Exegetical Syntax of the New Testament. Grand Rapids, MI: Zondervan, 1996.

Warren, Rick. The Purpose Driven Church - Gereja Yang Digerakkan Oleh Tujuan. 9th ed. Malang: Gandum Mas, 2012.

Yemima, K. "Strategi Pemuridan Mahasiswa Sekolah Tinggi Teologi Era New Normal Pandemi Covid-19." Jurnal Gamaliel: Teologi Praktika 2, no. 2 (2020).

https://nasional.kompas.com/read/2020/09/01/1528\%0Ahttp://jurnal.sttgamaliel.ac.id/index.php/gamaliel/article/view/56. 